Original Article

\title{
Amelioration potential of Moringa oleifera extracts against sodium arsenate induced embryotoxicity and genotoxicity in mouse (Mus musculus)
}

\author{
Potencial de melhoria de extratos de Moringa oleifera contra embriotoxicidade e \\ genotoxicidade induzida por arseniato de sódio em camundongos (Mus musculus)
}

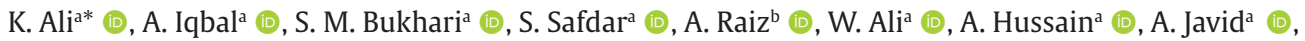



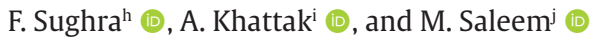

aUniversity of Veterinary \& Animal Sciences, Department of Wildlife \& Ecology, Lahore, Pakistan bDepartment of Zoology, GC Women University, Faisalabad, Pakistan

cUniversity of Veterinary \& Animal Sciences, Institute of Biochemistry and Biotechnology, Lahore, Pakistan

dUniversity of Veterinary \& Animal Sciences, Department of Poultry Production, Lahore, Pakistan

'Bahauddin Zakariya University, Department of Zoology, Multan, Pakistan

fGovernment College University, Department of Zoology, Lahore, Pakistan

gUniversity of Okara, Department of Zoology, Okara, Pakistan

hUniversity of Education, Department of Zoology, Division of Science \& Technology, Lahore, Pakistan

iDepartment of Bioinformatics, Shaheed Benazir Bhutto Women University, Peshawar, Pakistan

jDepartment of Zoology, Virtual University of Lahore, Lahore, Pakistan

\begin{abstract}
Previous studies have suggested that arsenic crosses the placenta and affects the fetus development. The study under consideration aims to show comparative ameliorative effect of Moringa oleifera leaf and flower extracts against sodium arsenate induced fetus toxicity of mice. Pregnant mice $(N=44)$ were kept in lab and divided into eleven group from (A to $\mathrm{K}$ ) and were orally administered the doses $6 \mathrm{mg} / \mathrm{kg}, 12 \mathrm{mg} / \mathrm{kg}$ for sodium arsenate, $150 \mathrm{mg} / \mathrm{kg}$ and $300 \mathrm{mg} / \mathrm{kg}$ for Moringa oleifera leaf extracts (MOLE) and $150 \mathrm{mg} / \mathrm{kg}$ and $300 \mathrm{mg} / \mathrm{kg}$ for Moringa oleifera flower extracts (MOFE) comparing with control. The investigation revealed evident reduction in the fetuses weight, hind limb, fore limb, tail and snout length, crown rump and head circumferences well as malformations in tail, feet, arms, legs, skin and eyes in the negative control group (only administered with sodium arsenate). Co-administration of sodium arsenate with MOLE and MOFE ameliorate the reversed effect of sodium arsenate on the shape, length, body weight and DNA damage of fetus significantly at 95\% confidence interval. However, Moringa oleifera leaf extract showed more significant results in comparison to Moringa oleifera flower extract. Hence concluded that Moringa oleifera leaf extract ameliorated the embryo toxic effects of sodium arsenate and can be used against environmental teratogens.
\end{abstract}

Keywords: Moringa oleifera, comet assay, deformed axis, laproschisis, rump.

\begin{abstract}
Resumo
Estudos anteriores sugeriram que o arsênio atravessa a placenta e afeta o desenvolvimento do feto. $\mathrm{O}$ estudo em consideração visa mostrar o efeito melhorador comparativo de extratos de folhas e flores de Moringa oleifera contra a toxicidade fetal induzida por arseniato de sódio em camundongos. Camundongos grávidas $(\mathrm{N}=44)$ foram mantidos em laboratório e divididos em 11 grupos (de A a K) e foram administrados por via oral nas doses de $6 \mathrm{mg} / \mathrm{kg}, 12 \mathrm{mg} / \mathrm{kg}$ para arseniato de sódio, $150 \mathrm{mg} / \mathrm{kg}$ e $300 \mathrm{mg} / \mathrm{kg}$ para extratos de folhas de Moringa oleifera (MOLE) e $150 \mathrm{mg} / \mathrm{kg}$ e $300 \mathrm{mg} / \mathrm{kg}$ para extratos de flores de Moringa oleifera (MOFE) em comparação com o controle. A investigação revelou redução evidente no peso do feto, membro posterior, membro anterior, comprimento da cauda e focinho, coroa, nádega e circunferência da cabeça, bem como malformações na cauda, pés, braços, pernas, pele e olhos no grupo de controle negativo (apenas administrado com arseniato de sódio). A coadministração de arseniato de sódio com MOLE e MOFE melhora significativamente o efeito reverso do arseniato de sódio na forma, comprimento, peso corporal e dano ao DNA do feto, com intervalo de confiança de 95\%. No entanto, o extrato da folha da Moringa oleifera apresentou resultados mais significativos em comparação ao extrato da flor da Moringa oleifera. Portanto, concluiu que o extrato da folha de Moringa oleifera melhorou os efeitos tóxicos do arseniato de sódio para o embrião e pode ser usado contra teratógenos ambientais.
\end{abstract}

Palavras-chave: Moringa oleifera, ensaio cometa, eixo deformado, laprosquise, alcatra.

*e-mail: asia.iqbal@uvas.edu.pk

Received: January 27, 2021 - Accepted: March 9, 2021

This is an Open Access article distributed under the terms of the Creative Commons Attribution License, which permits unrestricted use, distribution, and reproduction in any medium, provided the original work is properly cited. 


\section{Introduction}

Heavy metals like arsenic, copper, cadmium, lead, zinc, nickel, and chromium are usually found in water and dangerous to human beings and environment Jaishankar et al. (2014). Erosion of soil, weathering of rocks, industrial waste, urban sewage, pesticides, mining and other ways are common sources of heavy metals Morais et al. (2012). Arsenic is one of the dangerous heavy metal and abundantly found in earth crust. It has valency of (III) or (V) and found in inorganic and organic forms. Chile, Argentina, India, Nevada, California, China, Taiwan, Thailand, Mongolia, Mexico, North Dakota, Nepal and Central Oklahoma in USA are hotspots of arsenic in world for surface or groundwater (Abdul et al., 2015; Carlin et al., 2016). Arsenic is found in oxides or sulphides form of iron, calcium and sodium salts Singh et al. (2007). At earth, it is 20th plentiful metal. Inorganic arsenite and arsenates are dangerous to living things and environment. $10 \mathrm{ppb}$ is maximum arsenic value according to Brown and Ross (2002). Drinking water contamination with inorganic arsenic is globally found to be major health concern. Shakoor et al. (2015) studied the concentration of as in rural areas like Chichawatni, Rahim Yar Khan and Vihari of Punjab in Pakistan. 53\% out of 62 water samples showed the greater arsenic value than the WHO (World Health Organization) permissible limits $10 \mu \mathrm{g} / \mathrm{L}$. Arsenic values are 15 times greater than the WHO described safe limits in the ground water in different tehsils of district vehari Shahid et al. (2018). In Pakistan water pollution is major problem and peoples are affected with arsenic through contaminated water, pesticides, fruits, vegetables and other edibles with concentration more than WHO described limits Bahadar et al. (2014). Inorganic arsenic consumption effects seriously to human health and causes "arsenicosis" by low and long-term exposure to arsenic McCarty et al. (2011). Anemia, vascular disorders, respiratory and neuropathic disorders occur due to lower chronic arsenic exposure Trevor et al. (2010).

According to Chen et al. (2009) skin lesion, circulatory dysfunction, nervous disorders, liver and kidney disorder, diabetics and death occurs due to 10 to 300 microgram per liter of As. Bladder cancer risk increased in smoker when exposed to high doses of arsenic Wang et al. (2013). Chronic low dose exposure could cause DNA damage and inflammation Dutta et al. (2015). Tabacova et al. (1994) in his study concluded that placental levels of arsenic were greater in arsenic contaminated area and pregnant females were at risk of oxidative damage. It has been also found that arsenic crosses the placenta and affected the fetus development Dietert and Piepenbrink (2006). Preterm birth, mortality and reduced fetal weight have been observed Ahmed et al. (2011). DNA damage and oxidative stress, epigenetic modification, unstable the genome, induced carcinogenesis by inflammation and immune modulation. Hepatic damage, dermal, pulmonary, and pancreatic cancer is linked with exposure to higher arsenic and it also produces cardiovascular and nervous disorders Rao et al. (2017). In genotoxicity, genetic material (DNA and RNA) losses its properties due to destructive effects of genotoxic substances which may lead to several diseases including cancer Ray (2014). Comet assay could be used for evaluating DNA damage. In detection of DNA depletion and repairing comet assay is one of the best tool for prokaryotes and eukaryotes (Andem et al., 2013; Hansen et al., 2014).

Moringa oleifera Lam., synonym M. ptreygosperma Gaertn, family Moringaceae is commonly called drumstick, kelor or horse radish Anwar et al. (2005). It is commonly found in South Asia, Arabia, Africa, America, Pakistan, India, and Himalayan regions, islands of Caribbean and Pacific (Sreelatha and Padma, 2009). In Pakistan, Moringa concanensis and Moringa oleifera are present and widely cultured in moderate areas like, Punjab Plains, Sindh, NWFP and Balochistan. Antioxidants and nutraceuticals are present in large amount in leaves, flowers, seeds fruits and foods of Moringa oleifera Falowo et al. (2018). Moringa leaves contain protein, potassium, calcium, iron, vitamin, antioxidants like ascorbic acid, flavonoids, carotenoids, polyphenols, rutin, glycosides, which could be used as food in developing countries for nourishment (Siddhuraju and Becker, 2003; Ndong et al., 2007). Seed and flower have been used against arsenic induce toxicity in Albino rat by (Gupta et al., 2005; Chattopadhyay et al., 2011). Despite of above-mentioned beneficial effects of Moringa, its application against metallic toxicity, specifically against arsenic induced embryonic toxicity has not yet been studied. Higher intake of arsenic in drinking water may causes chronic embryo toxicity and tissue damage with genotoxic risk to the population. So, the confirmation of effectiveness of Moringa oleifera against arsenic induced embryo toxicity in mice was necessary which showed the beneficial effects of Moringa oleifera (extracts) against arsenic induced embryo toxicity during critical time of development.

\section{Materials and Methods}

\subsection{Mice sampling}

Albino Mice, Mus musculus (Temminck, 1845) ( $N=44)$ of 7-8 week, with initial body weight of $20-25 \mathrm{~g}$ was obtained from animal house of University of Veterinary and Animal sciences, Lahore. Ethical permission was obtained from the ethical committee of University of Veterinary and Animal sciences Lahore, Pakistan via Ref. No.161. Dated 6-2-2020.

The mice were kept under standard conditions i.e. temperature $25^{\circ} \mathrm{C}$ with 12 hours, dark and light cycle and treated with normal diet (National feed No. 14) which had Energy: $2700 \mathrm{Kcal} / \mathrm{Kg} \pm 100$, Crude Protien: $16.5 \% \pm 1$, with ingredients like cereals and corn. Tap water was given in plastic bottles to animals as ad-libitum. In Pregnant female mice, timed mating was induced by placing 1 male and 2 female together and presence of vaginal plug was the indication of mating. The observation of a plug determined the gestation day zero Rodriguez et al. (2016).

\subsection{Chemicals}

All chemicals like TCA, Triton X-100, Low and normal melting agarose, Tris, Ethidium bromide etc were purchased 
from Merck company, Germany while Sodium arsenate was obtained from Sigma chemicals, USA.

\subsection{Preparation of Moringa oleifera extracts}

Plant materials (leaves and flowers) were collected from the Botanical garden of UVAS, Ravi campus Pattoki. The method of extraction was given in report of Tabidi et al. (2018). The plant material was sun dried for 7 days, grounded into powdered form, and extracted through soxhlet apparatus with solvent. Extracted solvent air dried, stored at $4^{\circ} \mathrm{C}$ and was used with distilled water.

\subsection{Qualitative and quantitative analysis of extracts}

Qualitative and quantitative analysis of Moringa oleifera leaf and flower extracts for the presence or absence of phytochemicals were carried using standard procedures given in reports of Santhi and Sengottuvel (2016) and Adawia et al. (2016).

\subsection{Administration of sodium arsenate and extracts (MOFE and MOLE) to animals}

Toxicant sodium arsenate to induce embryo toxicity and test extracts (leaf and flower) of Moringa oleifera as ameliorant was used with different doses at GD8-GD12. Pregnant females were divided into groups (A, B, C, D, E, $\mathrm{F}, \mathrm{G}, \mathrm{H}, \mathrm{I}, \mathrm{J}$ and $\mathrm{K}$ ) with 4 pregnant females in each group. A continuous chronic dose of sodium arsenate at GD-8 to GD-12 was administered orally to the pregnant mice for induction embryonic abnormalities. Tested extract of Moringa oleifera leaf and flower was also administered orally with following doses as given below, 1hour before sodium arsenate administration in all experimental groups. Where, Group A is of control while B and $C$ were sodium arsenate treated groups $(A(0.00), B(6.00,0.00), C(12.00$, $0.00) \mathrm{mg} / \mathrm{kg}$ B.W.) Where, groups $D$ to $G$ were sodium arsenate and $M$. oleifera flower extract treated groups. (D $(6.00,150.00), \mathrm{E}(6.00,300.00), \mathrm{F}(12.00,150.00)$ and $G$ $(12.00,300.00) \mathrm{mg} / \mathrm{kg} \mathrm{B.W.}$.) Where, groups $\mathrm{H}$ to K were sodium arsenate and $M$. oleifera leafextract treated groups. (H $(6.00,150.00), \mathrm{I}(6.00,300.00), \mathrm{J}(12.00,150.00)$ and $\mathrm{K}(12.00,300.00) \mathrm{mg} / \mathrm{kg}$ B.W.)All animals were observed daily to count mortality and morbidity. Gross maternal body weights were measured daily from GD0 to GD18.

\subsection{Fetuses samples collection}

Pregnant females were anaesthetized at GD18 using ether presented on a cotton ball and fetuses were obtained surgically. Fetuses were weighed and photographed in situ for morphological studies. Litters were observed through count, deceased, normal and abnormal fetus. Extra embryonic surroundings were cleared and formalin $10 \%$ was used to fix fetuses for $48 \mathrm{hrs}$, after this kept in $70 \%$ alcohol Carson and Hladik (1997). Fetuses with more morphological defects (caraniofacial, trunk, limbs, tail and axis) were selected, recorded and tabulated. Verniercalliper was used for morphometric studies (Head circumference, nasal length, tail length, crown rump length, fore and hind limbs length).
Comet assay was used to check the DNA damage according to report of Andem et al. (2013). Briefly, 1\% normal melting agarose (NMA $3 \mathrm{gm}+3 \mathrm{~mL}$ PBS) was used to precoat the slides. Embryonic tissues were chopped in $2 \mathrm{~mL}$ of lysis solution with ice. Homogenized solution was filtered, centrifuged at $3000 \mathrm{rpm}$ for 20 minutes. Supernatants were transferred into new Eppendorf tube and pellets were discarded. Phosphate buffer saline (PBS) $1 \%$ was added and centrifuged for 5-7 min. at $3000 \mathrm{rpm}$. 10 to $20 \mu \mathrm{L}$ of pellet was mixed with 80 to $100 \mu \mathrm{L}$ of LMA (Low melting agarose) and spread on the precoated slides. Covered these slides with cover slips and placed on ice slab for 10 minutes, then placed upright in lysis buffer for two hour. Prepared Slides were completely dipped in alkaline buffer solution for 20 minutes. Slides were electrophoresed for 30 minutes and removed from electrophoresis apparatus. Samples stained with $1 \mathrm{X}$ Ethidium bromide. Comet score were obtained by the method of Ciğerci et al. (2015). 150 nuclei per slide was visually observed and counted at magnification of $400 \mathrm{X}$ using a fluorescent microscope (Olympus, Japan) and scored from 0-4 where 0 used stands for undamaged and 4 for maximum damage.

\subsection{Statistical analysis}

Statistical analysis SAS (version 9.1) software was used. ANOVA (Analysis of variance) was used to compare the means in all groups. $\mathrm{P}<0.05$ was considered significant and $5 \%$ was considered significance level for all analysis.

\section{Results}

Phytochemoical analyses of Moringa oleifera revealed that alkaloids, flavonoids, steroids, Phenols were rich than saponins and tanins. Currative potential of Moringa oleifera was due to huge amount of phytoconstituents like alkaloids, steroids, phenols and flavonoids as shown in Table 1.

Table 1. Phytochemical analysis of Moringa oleifera with methanol.

\begin{tabular}{lcc}
\hline \multicolumn{1}{c}{ Phytochemicals and Test } & $\begin{array}{c}\text { Leaves } \\
\text { extract }\end{array}$ & $\begin{array}{c}\text { Flowers } \\
\text { extract }\end{array}$ \\
\hline Mayers Test for Alkolides & ++ & + \\
$\mathrm{H}_{2} \mathrm{SO}_{4}$ test for Flavonoids & ++ & + \\
Liebermann Burchard test for Steroids & + & + \\
Salkowski test for Terpenoids & + & + \\
Ferric Chloride test for Phenols & +++ & + \\
Frothing test Saponins & ++ & - \\
Ferric Chloride test for Tanins & + & + \\
Nitroprusside test for Glycosides & + & + \\
Ninhydrin test for Protein & + & + \\
Molisch test for Carbohydrates & + & + \\
\hline
\end{tabular}

+++ = higher concentration; ++ = moderate; + = low concentrations; - = absent. 
Phenols, alkaloids, tannins, saponins and flavonoids were found in higher concentrations in Moringa oleifera leaf extract then the Moringa oleifera flower extract while saponins were absent in Moringa oleifera flower extract (Table 1).

\subsection{Gross fetus analysis}

Four females were used for each group. After fetuses recovery at GD18, gross fetus analysis was done in terms of total number of fetuses obtained, normal, abnormal and resorbed fetuses (Figure 1). Significant results were obtained from all experimental groups as compared to control while Moringa oliefera leaf extract treated groups showed significant results against sodium arsenate treated groups $\mathrm{B}$ and $\mathrm{C}$ as shown in Figure 1.

\subsection{Morphometric studies}

Morphometric analysis showed that fetuses weight, hind limb, fore limb, tail and snout length, crown rump and head circumference decreased significantly $(\mathrm{P}<0.05)$ in sodium arsenate treated groups B and C (Table 2 ) as compared to control group. While Moringa oleifera leaf extract treatment at a dose of $300 \mathrm{mg} / \mathrm{kg}$ B.W. showed significant amelioration against sodium arsenate induced morphometric abnormalities than the Moringa oleifera flower extract.

\subsection{Morphological studies}

All the experimental groups showed significant variation in morphological features with control group except group I (SA6 + MOLE $300+6 \mathrm{mg} / \mathrm{kg}$ B.W) treated with Moringa oliefera leaf extract which reduced the toxic effects of sodium arsenate as compared to Moringa oliefera flower extract treatment. Sodium arsenate at dose of $6 \mathrm{mg}$ / kg B.W (group B) and $12 \mathrm{mg} / \mathrm{kg} \mathrm{B.W}$ (groups C) showed abnormalities like hemorrhages, macroglossia, kinky tail, deformed body, cryptothalmia, low set arm, laprocrisis, club feet, omphocoel, micromelia, neck fissure, synotia, anotia, elongated snout, disstorted axis, anopthalmia and resorbed ovaries. Similarly, other groups excluding control (A) showed anomalies like macrotia, anotia, skin lesion, and open eyelids as shown in Figure 2.

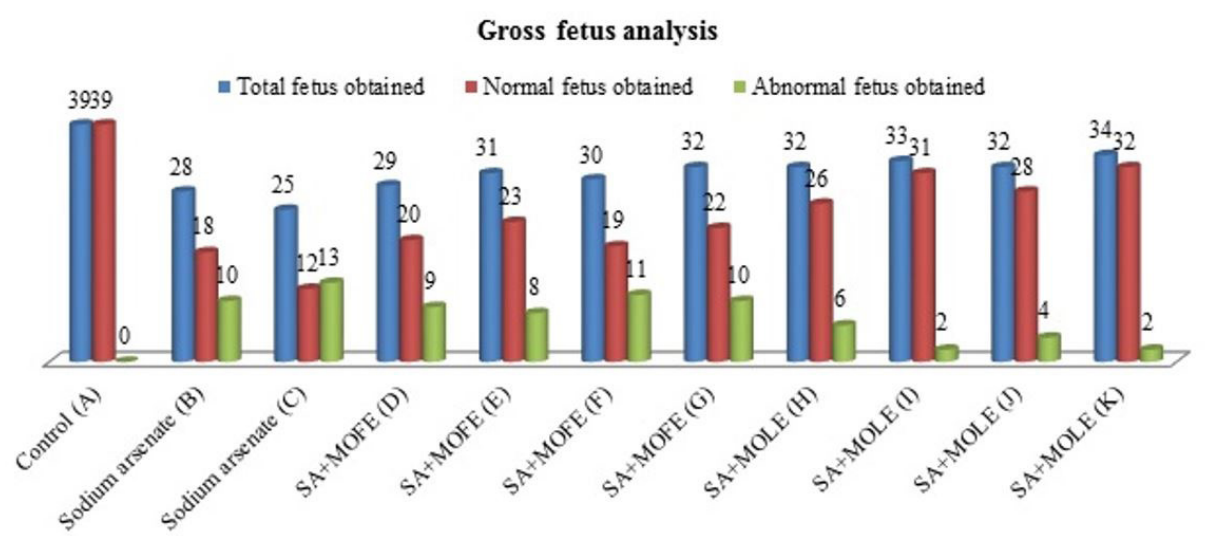

Figure 1. Gross fetus analysis of fetuses recovered at GD18.

Table 2. Morphomatric analysis fetuses recovered at GD18 from sodium arsenate and Moringaoliefera leaf and flower extract treated groups at gestation day 8-12 in mice.

\begin{tabular}{lccc}
\hline \multicolumn{1}{c}{ Treatment Groups } & Doses $(\mathbf{m g} / \mathbf{k g} / \mathbf{B . w})$ & Maternal IBW (Mean \pm SD) & Maternal FBW (Mean \pm SD) \\
\hline Control (A) & - & $25 \pm 0.81$ & $44 \pm 1.15^{\mathrm{a}}$ \\
Sodium arsenate(B) & 6 & $23.2 \pm 0.95$ & $30.5 \pm 1.29^{\mathrm{g}}$ \\
Sodium arsenate(C) & 12 & $25 \pm 0.81$ & $30 \pm 0.81^{\mathrm{g}}$ \\
SA+MOFE (D) & $6+150$ & $23.2 \pm 0.95$ & $33.2 \pm 0.50^{\mathrm{f}}$ \\
SA+MOFE (E) & $6+300$ & $23.2 \pm 0.95$ & $30.7 \pm 0.95^{\mathrm{g}}$ \\
SA+MOFE (F) & $12+150$ & $24.7 \pm 0.95$ & $35.5 \pm 0.57^{\mathrm{e}}$ \\
SA+MOFE (G) & $12+300$ & $23 \pm 0.81$ & $35.7 \pm 0.95^{\mathrm{e}}$ \\
SA+MOLE (H) & $6+150$ & $24.2 \pm 0.50$ & $38.2 \pm 0.95^{\mathrm{d}}$ \\
SA+MOLE (I) & $6+300$ & $23.2 \pm 0.95$ & $42.2 \pm 0.50^{\mathrm{b}}$ \\
SA+MOLE (J) & $12+150$ & $24.7 \pm 0.95$ & $39.2 \pm 0.50^{\mathrm{d}}$ \\
SA+MOLE (K) & $12+300$ & $23.5 \pm 1.29$ & $40.5 \pm 0.57^{\mathrm{c}}$ \\
\hline
\end{tabular}

Values bearing the same letters are insignificant and vice versa $(\mathrm{P}<0.05)$. Where, $\mathrm{SA}=$ Sodium arsenate, MOFE = Moringa oleifera flower extract; and MOLE $=$ Moringa oleifera leaf extract. 


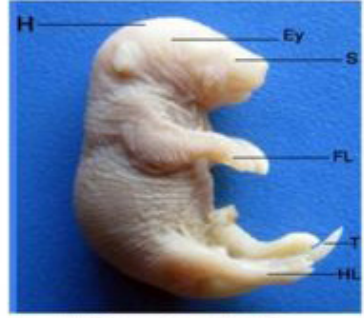

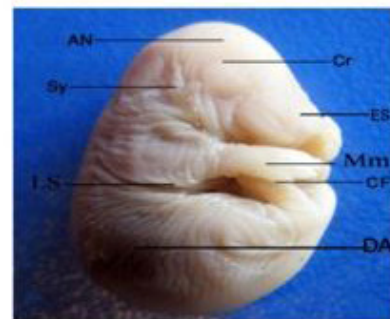

B(SA 6mg) $9 X$

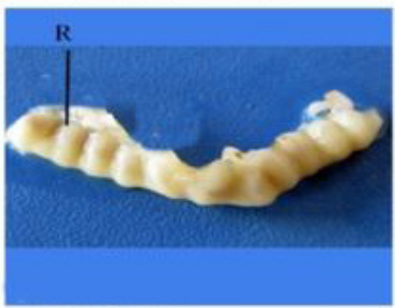

С3(SA 12mg) 15X

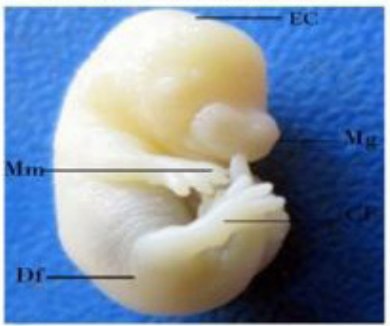

F(SA 12mg+MF150mg)15X

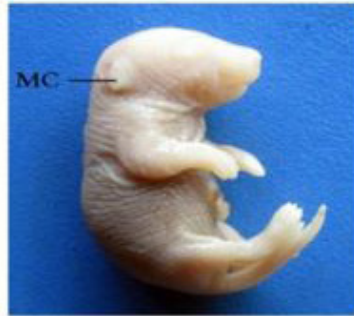

I(SA6mg+ML300mg) 7X

\section{$A($ Control)7X}

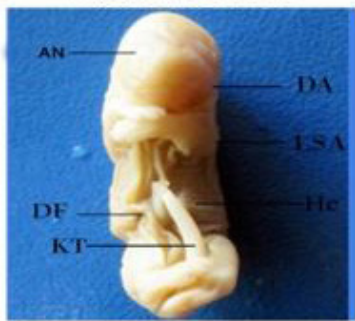

C1(SA 12mg) $9 x$

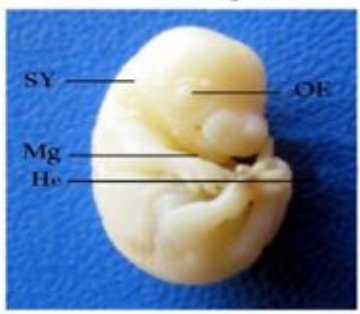

$D(S A$ 6mg+MF150mg) $15 X$

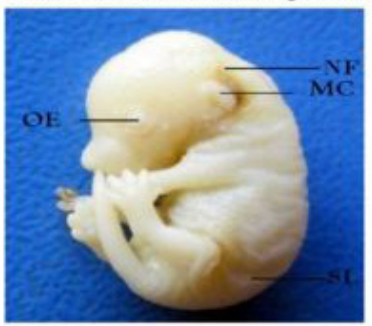

G(SA 12mg+MF300mg) $15 \times$



J(SA 12mg+ML150mg) $9 X$



C2(SA 12mg) 15X

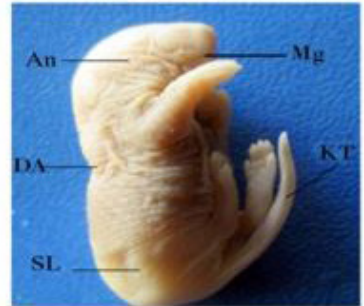

$E(S A 6 m g+M F 300 m g) 9 X$

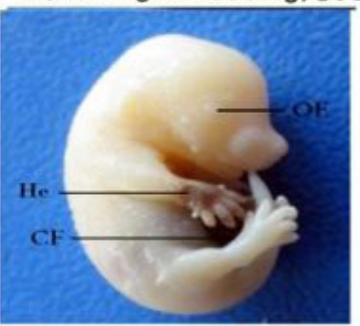

H(SA6mg+ML150mg)9X

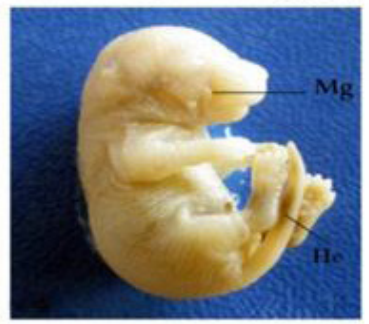

$\mathrm{K}(\mathrm{SA} 12 \mathrm{mg}+\mathrm{ML} 300 \mathrm{mg}) 9 \mathrm{X}$

Figure 2. Morphological features of mice fetuses recovered at GD18 administered with different doses of sodium arsenate and Moringa leaf and flower extracts given above. $\mathrm{H}=$ Head; $\mathrm{Ey}=\mathrm{Eye} ; \mathrm{FL}=$ Fore Limb; $\mathrm{HL}=$ Hind Limb; $\mathrm{S}=$ Snout; $\mathrm{T}=$ Tail; $\mathrm{DA}=$ Distorted Axis; $\mathrm{DF}$ = Deformed; $\mathrm{He}=$ Hemorrhage; $\mathrm{KT}=$ Kinky Tail; $\mathrm{NF}=$ Neck Fissure; $\mathrm{OE}=$ Open Eyelid; $\mathrm{Mm}=$ Micromelia; $\mathrm{Sl}=\mathrm{Skin}$ Lesion; $\mathrm{CF}=\mathrm{Club}$ Feet; $\mathrm{mg}$ = Macroglossia; Ls = Laproschisis; Mc = Macrotia; Es = Enlarge Snout; $\mathrm{Cr}=$ Cryptothalmia; An = Anopthalmia; Sy = Synotia; $\mathrm{An}=$ Anotia; $\mathrm{OM}=$ Omphocoel; $\mathrm{R}=$ Resorbed Ovary; $\mathrm{LSA}=$ Low Set Arm; Ec = Exencephaly.

\subsection{Comet assay}

The results of comet assay (Table 3) showed dose dependent response in all groups. Statistically significant difference $(\mathrm{P}<0.05)$ for all treatment groups was observed as compared to control group $(27.50 \pm 1.29)$ except in Moringa oleifera leaf extract (Group I) which showed similarity $(28.50 \pm 1.29)$ with control while sodium arsenate treated groups at dose of $6 \mathrm{mg} / \mathrm{kg}$ B.W. and $12 \mathrm{mg} / \mathrm{kg}$ B.W. 
Table 3. Genotoxic effects of sodium arsenate on mice embryo and ameliorative effect of Moringaoliefera extracts (leaf and flower).

\begin{tabular}{|c|c|c|c|c|c|c|c|}
\hline $\begin{array}{c}\text { Doses groups } \\
\mathrm{mg} / \mathrm{kg} / \mathrm{B} . W\end{array}$ & $\begin{array}{l}\text { Fetuses weight } \\
\text { (mg) }\end{array}$ & $\begin{array}{l}\text { Hind } \operatorname{limb} \\
\quad(\mathrm{mm})\end{array}$ & $\begin{array}{c}\text { Fore } \operatorname{limb} \\
(\mathbf{m m})\end{array}$ & $\begin{array}{l}\text { Tail length } \\
(\mathrm{mm})\end{array}$ & $\begin{array}{l}\text { Snout length } \\
(\mathrm{mm})\end{array}$ & $\begin{array}{l}\text { Crown rump } \\
\text { length (mm) }\end{array}$ & $\begin{array}{c}\text { Head } \\
\text { circumference } \\
(\mathbf{m m})\end{array}$ \\
\hline (A) Control & $1330.12 \pm 16.03^{a}$ & $10.13 \pm 0.46^{\mathrm{a}}$ & $9.26 \pm 0.44^{\mathrm{a}}$ & $13.49 \pm 0.19^{a}$ & $4.48 \pm 0.20^{\mathrm{a}}$ & $15.38 \pm 0.16^{\mathrm{a}}$ & $21.52 \pm 0.81^{\mathrm{a}}$ \\
\hline (B) $\mathrm{SA} 6 \mathrm{mg}$ & $530.64 \pm 16.67^{g}$ & $5.58 \pm 0.15^{\mathrm{hi}}$ & $4.45 \pm 0.17^{\mathrm{g}}$ & $6.54 \pm 0.36^{\mathrm{i}}$ & $3.40 \pm 0.19^{f}$ & $8.01 \pm 0.11^{\mathrm{i}}$ & $13.07 \pm 0.08^{\mathrm{h}}$ \\
\hline (C) SA $12 \mathrm{mg}$ & $494.08 \pm 54.56^{\mathrm{h}}$ & $5.51 \pm 0.13^{\mathrm{b}}$ & $4.44 \pm 0.14^{\mathrm{g}}$ & $6.47 \pm 0.25^{\mathrm{i}}$ & $3.37 \pm 0.15^{\mathrm{f}}$ & $7.98 \pm 0.07^{\mathrm{i}}$ & $13.06 \pm 0.09^{h}$ \\
\hline $\begin{array}{l}\text { (D) SA+MOFE } \\
6 \mathrm{mg}+150 \mathrm{mg}\end{array}$ & $540.79 \pm 27.23^{g}$ & $5.81 \pm 0.08^{g}$ & $5.41 \pm 0.34^{e}$ & $6.80 \pm 0.55^{\mathrm{h}}$ & $3.52 \pm 0.17^{\mathrm{de}}$ & $8.43 \pm 0.14^{\mathrm{h}}$ & $15.49 \pm 0.10^{\mathrm{f}}$ \\
\hline $\begin{array}{l}\text { (E) SA+MOFE } \\
6 \mathrm{mg}+300 \mathrm{mg}\end{array}$ & $933.58 \pm 27.86^{c}$ & $8.66 \pm 0.49^{d}$ & $7.39 \pm 0.49^{c}$ & $11.86 \pm 0.81^{c}$ & $3.67 \pm 0.10^{c}$ & $13.18 \pm 0.28^{c}$ & $20.25 \pm 0.34^{\mathrm{b}}$ \\
\hline $\begin{array}{l}\text { (F) SA+MOFE } \\
12 \mathrm{mg}+150 \mathrm{mg}\end{array}$ & $707.50 \pm 2.54^{\mathrm{e}}$ & $5.70 \pm 0.10 g^{h}$ & $5.05 \pm 0.15^{f}$ & $7.35 \pm 0.18^{g}$ & $3.45 \pm 0.05^{\mathrm{ef}}$ & $8.90 \pm 0.10^{g}$ & $13.93 \pm 0.20^{\mathrm{g}}$ \\
\hline $\begin{array}{l}\text { (G)SA+MOFE } \\
12 \mathrm{mg}+150 \mathrm{mg}\end{array}$ & $773.48 \pm 20.81^{\mathrm{d}}$ & $7.25 \pm 0.26^{\mathrm{e}}$ & $6.57 \pm 0.28^{\mathrm{d}}$ & $9.66 \pm 0.31^{\mathrm{d}}$ & $3.57 \pm 0.16^{\mathrm{cd}}$ & $12.51 \pm 0.28^{\mathrm{d}}$ & $19.30 \pm 0.70^{c}$ \\
\hline $\begin{array}{l}\text { (H)SA+MOLE } \\
6 \mathrm{mg}+150 \mathrm{mg}\end{array}$ & $609.00 \pm 1.01^{\mathrm{f}}$ & $5.88 \pm 0.11^{\mathrm{f}}$ & $5.06 \pm 0.16^{f}$ & $7.78 \pm 0.19^{f}$ & $3.41 \pm 0.03^{e}$ & $9.73 \pm 0.25^{f}$ & $15.93 \pm 0.39^{e}$ \\
\hline $\begin{array}{l}\text { (I) SA+MOLE } \\
6 \mathrm{mg}+300 \mathrm{mg}\end{array}$ & $1328.43 \pm 17.75^{\mathrm{a}}$ & $9.69 \pm 0.23^{b}$ & $8.17 \pm 0.43^{b}$ & $13.03 \pm 0.57^{b}$ & $4.46 \pm 0.49^{\mathrm{a}}$ & $15.26 \pm 0.46^{\mathrm{a}}$ & $20.42 \pm 0.54^{b}$ \\
\hline $\begin{array}{l}\text { (J) } S A+M O L E \\
12 \mathrm{mg}+150 \mathrm{mg}\end{array}$ & $718.90 \pm 11.12^{\mathrm{e}}$ & $9.29 \pm 0.23^{f}$ & $5.51 \pm 0.16^{\mathrm{e}}$ & $8.09 \pm 0.03^{e}$ & $3.65 \pm 0.20^{c}$ & $10.28 \pm 0.34^{e}$ & $16.44 \pm 0.78^{d}$ \\
\hline $\begin{array}{l}\text { (K)SA+MOLE } \\
12 \mathrm{mg}+300 \mathrm{mg}\end{array}$ & $1287.67 \pm 20.60^{\mathrm{b}}$ & $9.12 \pm 0.67^{c}$ & $8.14 \pm 0.25^{\mathrm{b}}$ & $11.84 \pm 0.73^{c}$ & $4.19 \pm 0.17^{b}$ & $14.50 \pm 1.07^{\mathrm{b}}$ & $20.37 \pm 1.34^{\mathrm{b}}$ \\
\hline
\end{tabular}

Values bearing the same letters are insignificant and vice versa $(\mathrm{P}<0.05)$. Where, $\mathrm{SA}=$ Sodium arsenate; MOFE = Moringa oleifera flower extract; and MOLE $=$ Moringa oleifera leaf extract.

showed greatest DNA damage as $66.25 \pm 2.21$ and 85.00 \pm 2.94 respectively (Table 3 ).

\section{Discussion}

This study was focused to explore the effectiveness of Moringa oleifera leaf and flower extracts against sodium arsenate induced embryo toxicity during critical time of development. Arsenic is causing embryonic abnormalities and nervous disorders during neurolation Robinson et al. (2011). Mutagenic, carcinogenic, and teratogenic effects were observed when exposed to high level of arsenic Shi et al. (2004). From all the teratogens, arsenic is the most common teratogen, this teratogenicity was confirmed by Hill et al. (2008). Arsenic exposure causes the DNA damage and oxidation of DNA. These DNA strand breakage were due to ROS (Reactive Oxidative Species) induced by arsenic Shi et al. (2004). Phytochemicals had ability to combat with free radicals and phenolics are one of these compounds which have antioxidative property Wangensteen et al. (2004). Moringa oliefera is a rich source of antioxidants in its leaf, flowers and seed (Morton, 1991; Sreelatha and Padma, 2009). Moringa bioactive compounds like polyphenolics can act against teratogens which are generating ROS (respiratory oxidative species) like arsenic which induces oxidative stress and DNA damage in mice Sikder et al. (2013). Antioxidating mechanism of Moringa oleifera bioactive compounds was used to check the effective potential of Moringa oleifera extracts against heavy metals induced embryotoxicity.
Results of our studies showed hemorrhages, macroglossia, kinky tail, deformed body, cryptothalmia, low set arm, laprocrisis, club feet, omphocoel, micromelia, neck fissure, synotia, elongated snout, distorted axis, excencephaly, anopthalmia, resorbed ovaries and growth retardation when sodium arsenate was given orally to pregnant females. These abnormalities increased significantly with increase of dose and time which is an agreement with study of Arshad and Asmatullah (2017) they found micromelia, anopthalmia, resorbed ovaries and cryptothalmia when treated pregnant mice with sodium arsenate. Morphometric data reveals significant decrease in fetus weight, fore and hind limb, snout and crown rump length which is compliance with studies of Hopenhayn et al. (2003). He performed a study in cities where arsenic in water was in great amount whereas Arshad and Asmatullah (2017) studied embryo toxic effects of arsenic and found fetuses weight, size, crown rump and head circumference reduced significantly. While Moringa oliefera leaf and flower extracts minimizes the sodium arsenate induced morphometric and morphological abnormalities of fetuses which is accordance with study of Zeng et al. (2019) who observed improved litter size, birth weight and fetus size and litter survival with Moringa oleifera leaf. In recent study leaf extract showed better results as compared to Moringa oleifera flower extract at a dose of MOLE $300 \mathrm{mg} / \mathrm{kg}$ B.W and ameliorated all the toxic effects of arsenic.

The results of comet assay to check the genotoxicity (DNA damage) induced by sodium arsenate and 
ameliorative potential of Moringa oleifera flower and leaf extracts showed that greatest damage was observed in only sodium arsenate treated groups ( $C \& D)$. In the present study arsenic at a dose of $12 \mathrm{mg} / \mathrm{kg}$ B.W. showed significant DNA damage than the dose of $6 \mathrm{mg} / \mathrm{kg}$ B.W. It is due to greater dose concentrations which generated more ROS (Reactive Oxidative Species) and causes the DNA damage Kohen and Gati (2000). Phytochemicals can neutralize this oxidative stress acting as radical savengers Arouma (2002). In findings that MOlE and MOFE prevents the DNA damage induced by sodium arsenate (Table 3 ). The extracts have free radical scavenging activity which is an agreement with study of De Bont and Van Larebeke (2004). These findings are in agreement with studies of Sinha et al. (2011) and Das et al. (2012). They had checked the antioxidant efficacy of MOLE. Amelioration of MOLE at a dose of $300 \mathrm{mg} / \mathrm{kg}$ B.W. was found against sodium arsenate induced genotoxicity. Present study gives the first validation that how Moringa oleifera can provide protection with its bioactive compounds against environmental teratogens like heavy metals specifically arsenic which induces developmental toxicity like DNA damage, morphometric and morphological anomalies.

\section{Conclusion}

Administration of sodium arsenate during organogenesis of developing mice embryo at doses $6 \mathrm{mg} / \mathrm{kg}$ and $12 \mathrm{mg} / \mathrm{kg}$ induced morphological malformations like hemorrhages, macroglossia, kinky tail, deformed body, cryptothalmia, low set arm, laprocrisis, club feet, omphocoel, micromelia, neck fissure, synotia, anotia, elongated snout, disstorted axis, anopthalmia, resorbed ovaries, macrotia, anotia, skin lesion, and open eyelids as well as reduction in the fetuses weight, hind limb, fore limb, tail and snout length, crown rump and head circumference.. Also, the treatment of Sodium arsenate increased the DNA damage. Administration of Sodium arsenate with MOLE and MOFE ameliorates the reversed effect of sodium arsenate because of bioactive compounds like phenols, flavonoids, and alkaloids. These compounds are more concentered in leaves and that's why MOLE shows more evident ameliorating effect in comparison to MOFE. This study presented the medicinal value of phytoconstituents of the Moringa oleifera specifically leaf against teratogenic elements as well as the hazardous effects of sodium arsenate, percolating in our environment, on the fetus development.

\section{References}

ABDUL, K.S.M., JAYASINGHE, S.S., CHANDANA, E.P., JAYASUMANA, C. and SILVA, P.M.C., 2015. Arsenic and human health effects: A review. Environmental Toxicology and Pharmacology, vol. 40, no. 3, pp. 828-846. http://dx.doi.org/10.1016/j.etap.2015.09.016. PMid:26476885.

ADAWIA, K., RAWAA, A.K. and GHALIA, S., 2016. Phytochemical screening and antioxidant activity of selected wild plants in Liliaceae family growing Syria. International Journal of Pharmacology \& Phytochemical Research, vol. 8, no. 2, pp. 2025-2032.
AHMED, S., KHODA, S.M.E., REKHA, R.S., GARDNER, R.M., AMEER, S.S., MOORE, S., EKSTRÖM, E.C., VAHTER, M. and RAQIB, R., 2011. Arsenic-associated oxidative stress, inflammation, and immune disruption in human placenta and cord blood. Environmental Health Perspectives, vol. 119, no. 2, pp. 258-264. http://dx.doi. org/10.1289/ehp.1002086. PMid:20940111.

ANDEM, A.B., AGBOR, R.B. and EKPO, I.A., 2013. Review on comet assay: a reliable tool for assessing DNA damage in animal models. Journal of Current Research in Science, vol. 1, no. 6, pp. 405.

ANWAR, F., ASHRAF, M. and BHANGER, M.I., 2005. Interprovenance variation in the composition of Moringa oleifera oilseeds from Pakistan. Journal of the American Oil Chemists' Society, vol. 82, no. 1, pp. 45-51. http://dx.doi.org/10.1007/s11746-005-1041-1.

AROUMA, O.I., 2002. Free radicals, oxidative stress, and antioxidants in human health and disease. Nutrition, vol. 18, pp. 872-879.

ARSHAD, M. and ASMATULLAH, C.A., 2017. Embryotoxic effects of sodium arsenate in Mus musculus. Punjab University Journal of Zoology, vol. 32, no. 2, pp. 189-195.

BAHADAR, H., MOSTAFALOU, S. and ABDOLLAHI, M., 2014. Growing burden of diabetes in Pakistan and the possible role of arsenic and pesticides. Journal of Diabetes and Metabolic Disorders, vol. 13, no. 1, pp. 117. http://dx.doi.org/10.1186/s40200-014-0117-y. PMid:25530951.

BROWN, K.G. and ROSS, G.L., 2002. Arsenic, drinking water, and health: a position paper of the American Council on Science and Health. Regulatory Toxicology and Pharmacology, vol. 36, no. 2, pp. 162-174. http://dx.doi.org/10.1006/rtph.2002.1573. PMid:12460751.

CARLIN, D.J., NAUJOKAS, M.F., BRADHAM, K.D., COWDEN, J., HEACOCK, M., HENRY, H.F., LEE, J.S., THOMAS, D.J., THOMPSON, C., TOKAR, E.J., WAALKES, M.P., BIRNBAUM, L.S. and SUK, W.A., 2016. Arsenic and environmental health: state of the science and future research opportunities. Environmental Health Perspectives, vol. 124, no. 7, pp. 890-899. http://dx.doi. org/10.1289/ehp.1510209. PMid:26587579.

CARSON, F.L. and HLADIK, C., 1997. Histotechnology: a selfinstructional text. Chicago: ASCP Press, vol. 96, pp. 189-202.

CHATTOPADHYAY, S., MAITI, S., MAJI, G., DEB, B., PAN, B. and GHOSH, D., 2011. Protective role of Moringaoleifera (Sajina) seed on arsenic-induced hepatocellular degeneration in female albino rats. Biological Trace Element Research, vol. 142, no. 2, pp. 200-212. http://dx.doi.org/10.1007/s12011-010-8761-7. PMid:20661662.

CHEN, Y., PARVEZ, F., GAMBLE, M., ISLAM, T., AHMED, A., ARGOS, M., GRAZIANO, J.H. and AHSAN, H., 2009. Arsenic exposure at low-to-moderate levels and skin lesions, arsenic metabolism, neurological functions, and biomarkers for respiratory and cardiovascular diseases: review of recent findings from the Health Effects of Arsenic Longitudinal Study (HEALS) in Bangladesh. Toxicology and Applied Pharmacology, vol. 239, no. 2, pp. 184-192. http://dx.doi.org/10.1016/j.taap.2009.01.010. PMid:19371619.

CIĞERCI, İ.H., LIMAN, R., ÖZGÜL, E. and KONUK, M., 2015. Genotoxicity of indium tin oxide by Allium and Comet tests. Cytotechnology, vol. 67, no. 1, pp. 157-163. http://dx.doi. org/10.1007/s10616-013-9673-0. PMid:24337653.

DAS, N., SIKDER, K., GHOSH, S., FROMENTY, B. and DEY, S., 2012. Moringa oleifera Lam. leaf extract prevents early liver injury and restores antioxidant status in mice fed with high-fat diet. Indian Journal of Experimental Biology, vol. 50, no. 6, pp. 404412. PMid:22734251.

DE BONT, R. and VAN LAREBEKE, N., 2004. Endogenous DNA damage in humans: a review of quantitative data. Mutagenesis, vol. 19, 
no. 3, pp. 169-185. http://dx.doi.org/10.1093/mutage/geh025. PMid:15123782.

DIETERT, R.R. and PIEPENBRINK, M.S., 2006. Perinatal immunotoxicity: why adult exposure assessment fails to predict risk. Environmental Health Perspectives, vol. 114, no. 4, pp. 477-483. http://dx.doi.org/10.1289/ehp.8566. PMid:16581533.

DUTTA, K., PRASAD, P. and SINHA, D., 2015. Chronic low level arsenic exposure evokes inflammatory responses and DNA damage. International Journal of Hygiene and Environmental Health, vol. 218, no. 6, pp. 564-574. http://dx.doi.org/10.1016/j. ijheh.2015.06.003. PMid:26118750.

FALOWO, A.B., MUKUMBO, F.E., IDAMOKORO, E.M., LORENZO, J.M., AFOLAYAN, A.J. and MUCHENJE, V., 2018. Multi-functional application of Moringa oleifera Lam. in nutrition and animal food products: a review. Food Research International, vol. 106, pp. 317-334. http://dx.doi.org/10.1016/j.foodres.2017.12.079. PMid:29579932.

GUPTA, R., KANNAN, G.M., SHARMA, M. and FLORA, S.J., 2005. Therapeutic effects of Moringa oleifera on arsenic-induced toxicity in rats. Environmental Toxicology and Pharmacology, vol. 20, no. 3, pp. 456-464. http://dx.doi.org/10.1016/j. etap.2005.05.005. PMid:21783626.

HANSEN, M.K., SHARMA, A.K., DYBDAHL, M., BOBERG, J. and KULAHCI, M., 2014. In vivo Comet assay-statistical analysis and power calculations of mice testicular cells. Mutation Research, vol. 774, pp. 29-40. http://dx.doi.org/10.1016/j. mrgentox.2014.08.006. PMid:25440908.

HILL, D.S., WLODARCZYK, B.J. and FINNELL, R.H., 2008. Reproductive consequences of oral arsenate exposure during pregnancy in a mouse model. Birth Defects Research. Part B, Developmental and Reproductive Toxicology, vol. 83, no. 1, pp. 40-47. http:// dx.doi.org/10.1002/bdrb.20142. PMid:18186108.

HOPENHAYN, C., FERRECCIO, C., BROWNING, S.R., HUANG, B., PERALTA, C., GIBB, H. and HERTZ-PICCIOTTO, I., 2003. Arsenic exposure from drinking water and birth weight. Epidemiology, vol. 14, no. 5, pp. 593-602. http://dx.doi.org/10.1097/01. ede.0000072104.65240.69. PMid:14501275.

JAISHANKAR, M., TSETEN, T., ANBALAGAN, N., MATHEW, B.B. and BEEREGOWDA, K.N., 2014. Toxicity, mechanism and health effects of some heavy metals. Interdisciplinary Toxicology, vol. 7, no. 2, pp. 60-72. http://dx.doi.org/10.2478/intox-2014-0009. PMid:26109881.

KOHEN, R. and GATI, I., 2000. Skin low molecular weight antioxidants and their role in aging and in oxidative stress. Toxicology, vol. 148, no. 2-3, pp. 149-157. http://dx.doi.org/10.1016/S0300483X(00)00206-7. PMid:10962134.

MCCARTY, K.M., HANH, H.T. and KIM, K.W., 2011. Arsenic geochemistry and human health in South East Asia. Reviews on Environmental Health, vol. 26, no. 1, pp. 71-78. http://dx.doi. org/10.1515/reveh.2011.010. PMid:21714384.

MORAIS, S., COSTA, F.G. and PEREIRA, M.D.L., 2012. Heavy metals and human health. Environmental Health-Emerging Issues and Practice, vol. 10, pp. 227-246.

MORTON, J.F., 1991. The horseradish tree, Moringa pterygosperma (Moringaceae): a boon to arid lands? Economic Botany, vol. 45, no. 3, pp. 318-333. http://dx.doi.org/10.1007/BF02887070.

NDONG, M., UEHARA, M., KATSUMATA, S., SATO, S. and SUZUKI, K., 2007. Preventive effects of Moringa oleifera (Lam) on hyperlipidemia and hepatocyte ultrastructural changes in iron deficient rats. Bioscience, Biotechnology, and Biochemistry, vol. 71, no. 8, pp. 1826-1833. http://dx.doi.org/10.1271/bbb.60644. PMid:17690476.
RAO, C.V., PAL, S., MOHAMMED, A., FAROOQUI, M., DOESCHER, M.P., ASCH, A.S. and YAMADA, H.Y., 2017. Biological effects and epidemiological consequences of arsenic exposure, and reagents that can ameliorate arsenic damage in vivo. Oncotarget, vol. 8, no. 34, pp. 57605-57621. http://dx.doi.org/10.18632/ oncotarget.17745. PMid:28915699.

RAY, S., 2014. Micronutrient, genome stability and degenerative diseases: nutrigenomics concept of disease prevention: an overview. Current Research in Nutrition and Food Science Journal, vol. 2, no. 3, pp. 159-164. http://dx.doi.org/10.12944/ CRNFSJ.2.3.08.

ROBINSON, J.F., YU, X., MOREIRA, E.G., HONG, S. and FAUSTMAN, E.M., 2011. Arsenic-and cadmium-induced toxicogenomic response in mouse embryos undergoing neurulation. Toxicology and Applied Pharmacology, vol. 250, no. 2, pp. 117-129. http:// dx.doi.org/10.1016/j.taap.2010.09.018. PMid:20883709.

RODRIGUEZ, K.F., UNGEWITTER, E.K., CRESPO-MEJIAS, Y., LIU, C., NICOL, B., KISSLING, G.E. and YAO, H.H.C., 2016. Effects of in utero exposure to arsenic during the second half of gestation on reproductive end points and metabolic parameters in female CD-1 mice. Environmental Health Perspectives, vol. 124, no. 3, pp. 336-343. http://dx.doi.org/10.1289/ehp.1509703. PMid:26295903.

SANTHI, K. and SENGOTTUVEL, R., 2016. Qualitative and quantitative phytochemical analysis of Moringa concanensis Nimmo. International Journal of Curative and Microbiology Applied Sciiences, vol. 5, no. 1, pp. 633-640. http://dx.doi.org/10.20546/ ijcmas.2016.501.064.

SHAHID, M., KHALID, M., DUMAT, C., KHALID, S., NIAZI, N.K., IMRAN, M., BIBI, I., AHMAD, I., HAMMAD, H.M. and TABASSUM, R.A., 2018. Arsenic level and risk assessment of groundwater in Vehari, Punjab Province, Pakistan. Exposure and Health, vol. 10, no. 4, pp. 229-239. http://dx.doi.org/10.1007/s12403-017-0257-7.

SHAKOOR, M.B., NIAZI, N.K., BIBI, I., RAHMAN, M.M., NAIDU, R., DONG, Z., SHAHID, M. and ARSHAD, M., 2015. Unraveling health risk and speciation of arsenic from groundwater in rural areas of Punjab, Pakistan. International Journal of Environmental Research and Public Health, vol. 12, no. 10, pp. 12371-12390. http://dx.doi.org/10.3390/ijerph121012371. PMid:26445051.

SHI, H., SHI, X. and LIU, K.J., 2004. Oxidative mechanism of arsenic toxicity and carcinogenesis. Molecular and Cellular Biochemistry, vol. 255, no. 1-2, pp. 67-78. http://dx.doi. org/10.1023/B:MCBI.0000007262.26044.e8. PMid:14971647.

SIDDHURAJU, P. and BECKER, K., 2003. Antioxidant properties of various solvent extracts of total phenolic constituents from three different agroclimatic origins of drumstick tree (Moringa oleifera Lam.) leaves. Journal of Agricultural and Food Chemistry, vol. 51, no. 8, pp. 2144-2155. http://dx.doi.org/10.1021/jf020444+. PMid: 12670148.

SIKDER, K., SINHA, M., DAS, N., DAS, D.K., DATTA, S. and DEY, S., 2013. Moringa oleifera Leaf extract prevents in vitro oxidative DNA damage. Asian Journal of Pharmaceutical and Clinical Research, vol. 6, no. 2, pp. 159-163.

SINGH, N., KUMAR, D. and SAHU, A.P., 2007. Arsenic in the environment: effects on human health and possible prevention. Journal of Environmental Biology, vol. 28, no. 2, suppl., pp. 359365. PMid:17929751.

SINHA, M., DAS, D.K., BHATTACHARJEE, S., MAJUMDAR, S. and DEY, S., 2011. Leaf extract of Moringa oleifera prevents ionizing radiation-induced oxidative stress in mice. Journal of Medicinal Food, vol. 14, no. 10, pp. 1167-1172. http://dx.doi.org/10.1089/ jmf.2010.1506. PMid:21861723. 
SREELATHA, S. and PADMA, P.R., 2009. Antioxidant activity and total phenolic content of Moringa oleifera leaves in two stages of maturity. Plant Foods for Human Nutrition, vol. 64, no. 4, pp. 303-311. http://dx.doi.org/10.1007/s11130-009-0141-0. PMid:19904611.

TABACOVA, S., BAIRD, D.D., BALABAEVA, L., LOLOVA, D. and PETROV, I., 1994. Placental arsenic and cadmium in relation to lipid peroxides and glutathione levels in maternal-infant pairs from a copper smelter area. Placenta, vol. 15, no. 8, pp. 873-881. http:// dx.doi.org/10.1016/S0143-4004(05)80188-2. PMid:7886027.

TABIDI, R.H., BABEKER, E.A., and ELLAITHI, S.O., 2018. Phytochemical and antibacterial of Moringa oleifera leaves. World Journal of Pharmaceutical Research, vol. 8, no. 2, pp. 212-224.

TREVOR, A.J., KATZUNG, B.G., MASTERS, S.B. and KRUIDERING-HALL, M., 2010. Pharmacology examination \& board review. New York: McGraw-Hill Medical.
WANG, Y.H., YEH, S.D., WU, M.M., LIU, C.T., SHEN, C.H., SHEN, K.H., PU, Y.S., HSU, L.I., CHIOU, H.Y. and CHEN, C.J., 2013. Comparing the joint effect of arsenic exposure, cigarette smoking and risk genotypes of vascular endothelial growth factor on upper urinary tract urothelial carcinoma and bladder cancer.Journal of Hazardous Materials, vol. 262, pp. 1139-1146. http://dx.doi. org/10.1016/j.jhazmat.2012.08.056. PMid:23009795.

WANGENSTEEN, H., SAMUELSEN, A.B. and MALTERUD, K.E., 2004. Antioxidant activity in extracts from coriander. Food Chemistry, vol. 88, no. 2, pp. 293-297. http://dx.doi.org/10.1016/j. foodchem.2004.01.047.

ZENG, B., LUO, J., WANG, P., YANG, L., CHEN, T., SUN, J., XIE, M., LI, M., ZHANG, H., HE, J., ZHANG, Y. and XI, Q., 2019. The beneficial effects of Moringa oleifera leaf on reproductive performance in mice. Food Science E'Nutrition, vol. 7, no. 2, pp. 738-746. http:// dx.doi.org/10.1002/fsn3.918. PMid:30847152. 